\title{
Modulating the Haematological and Cytogenetic Effects of Mitomycin C by Aqueous Extract of Nut Grass (Cyperus rotundus L.)
}

تعديل التأثيرات الامية والوراثية الخلوية للمايتومايسين سي باستخدام المستخلص

Ali H. Ad'hiah Mohammed M. F. Al-Halbosiy*

Rakad M. Al-Jumaily

Baghdad University/ College of Science/ Biology Department

* Al-Nahrain University/ Biotechnology Research Center

\begin{abstract}
The aqueous extract (5, 10 and $15 \mathrm{mg} / \mathrm{kg})$ of nut grass (Cyperus rotundus L.) rhizomes was evaluated orally in albino male mice using some haematological (total leucocyte count) and cytogenetic (mitotic index, micronucleus formation and chromosomal aberrations of bone marrow cells) parameters. The extract interaction with the mutagen mitomycin $\mathrm{C}$ (MMC) was also evaluated through two types of treatments (pre- and post-treatments). The results revealed that the dose $15 \mathrm{mg} / \mathrm{kg}$ of the extract significantly increased the total count of leucocytes (7634.4 vs. 6783.3 cells/cu.mm. blood), while the mitotic index showed no significant differences, as compared to negative controls. However, the spontaneous formation of micronuclei in the bone marrow cells was significantly decreased in the three investigated doses of the extract $(0.30,0.32$ and 0.29 , respectively $v s .0 .62 \%)$, while the chromosomal assay showed similar frequencies in the negative control and nut grass-treated animals. With respect to the interaction with MMC, the pre-treatment $(15 \mathrm{mg} / \mathrm{kg})$ enhanced the leucocyte count (10358.6 vs. 3800.2 cells/cu.mm.blood) and mitotic index (11.9 vs. 6.5\%), and a similar picture was drawn when the pos-treatment was considered (8884.2 vs. 4292.7 cells/cu.mm.blood; 14.6 vs. 7.6\%). However, the doses
\end{abstract}


5 and $10 \mathrm{mg} / \mathrm{kg}$ of the plant extract were much more effective in reducing the MMC-induced micronucleus formation in both types of treatments especially the dose $5 \mathrm{mg} / \mathrm{kg}$ (pre-treatment: 4.24 vs. 16.29\%; post-treatment: 3.79 vs. 14.34\%). With respect to chromosomal aberration assay, the dose $15 \mathrm{mg} / \mathrm{kg}$ of the extract was the most effective dose in reducing the MMC-induced aberrations, but the posttreatment was better than pre-treatment in this respect $\left(\begin{array}{llll}0.29 & \text { vs. } & 0.79\end{array}\right.$ aberration/cell).

قيمت التأثيرات الامية (عد خلايا الام البيض) والوراثية الخلويـة (معامل الأنقسـام وتكون النـوى الصغغيرة والزيـغ الكروموسومي لخلايا نقي العظم) للمستخلص المائي لنبات السعد 51015 ملفم/كفم في ذكور الفئران البيض.

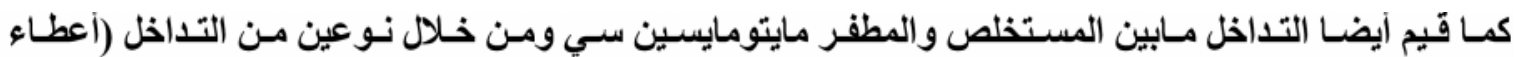
) . أظهرت النتائج بأن الجرعة 15 ملفف/ كفم كاتت فعالة في رفع معدل عد خلايـا اللام

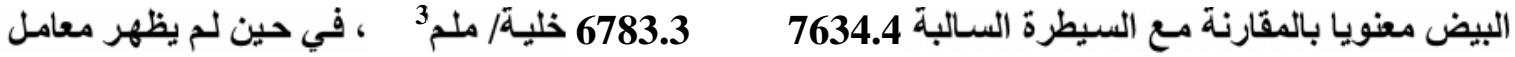
نقسام أي فروق معنوية ـ أما النسبة المئوية للتكون التلقائي للنوى الصغغيرة فقد أظهر أنخفاضـا معنويـا واضحا

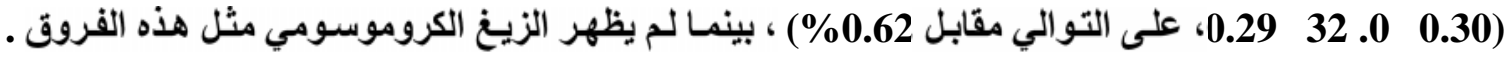

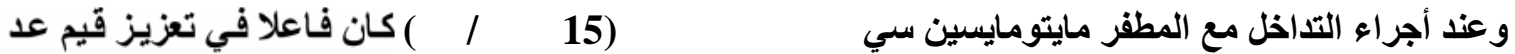

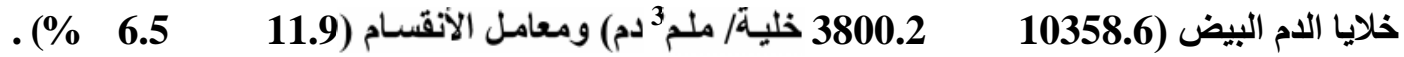

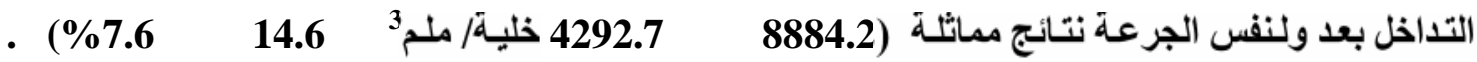
ـ الصغيرة والمستحث بالمطفر مايتومايسين سي فقد أنخفض معنويـا في الجرعتين 510 /

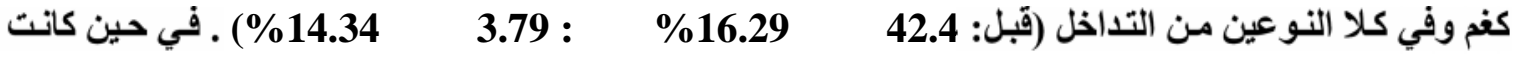
15 ملفم/ كفم هي الاقضل في خفض معدل الزيغ الكروموسومي المستحث بـالمطفر مايتومايسين سي ولكن كانت نتائج التداخل بعد هي الأفضل (0.29 0.79 ) م

\section{Introduction}

Nut grass (Cyperus rotundus L.) is a medicinal plant with wide applications in folkloric medicine. The plant is a pestiferous perennial weed, arising from a system of underground rhizomes, and the latter are the principle focus in medicinal applications (1). Many pharmaceutical properties of nut grass have been described; some of them are documented by folkloric medicine, while others have been revealed by some scientific publications Tho 1sttor 
approaches have suggested that the plant alone or in a combination with other plants may have some medicinal effects, which are antimicrobial (2), antimalarial (3) and anti-inflammatory (4). These effects have been ascribed to some active phytopharmaceutical components of the plant, for instances, flavonoids, essential oils, polyphenols, ascorbic acid and oleanolic acid (5). The plant has also been qualified as immunostimulant,

\section{Materials and Methods}

Laboratory Animals: The experiments were carried out on albino male mice (Mus musculus), which were supplied by Tropical Disease Research Unit, University of Baghdad. Their age was 910 weeks, and during the experiments, they had free access to water and food (ad libitum), and were caged in the animal house at a temperature $23 \pm 3^{\circ} \mathrm{C}$., with light:dark periods of 14:10 hours.

Preparation of Plant Extract: The dried rhizomes of $C$. rotundus were purchased from a local medicinal plant store in Baghdad, and identified by Professor Ali Al-Mosawy (College of Science, University of Baghdad). The rhizomes were powdered using a coffee grinder, and 50 grams of the powder antioxidant and antitumour $(6,7)$. These documentations augmented the present investigation with the aim to shed some light on the effects of aqueous extract of the plant rhizome powder on the total leucocyte count, mitotic index, micronucleus formation and chromosomal aberrations in albino male mice. The role of the extract in reducing the effects of the mutagen mitomycin $\mathrm{C}$ (MMC) was also evaluated.

were extracted by means of Soxhlet using distilled water as a solvent. The aqueous extract was evaporated using rotary evaporator $\left(80^{\circ} \mathrm{C}\right)$, and the residue was dissolved in distilled water to prepare the required doses $(5,10$ and 15 $\mathrm{mg} / \mathrm{kg}$ ).

Experimental Design: The plant extract effect was evaluated in the animals through two types of experiments. In the first, $0.25 \mathrm{ml}$ of each dose was given orally to the animals (number $=6$ ) for seven days, and in day 8, they were investigated. Two control samples were included in this experiment; negative control (dosed with distilled water) and positive control (dosed with MMC). In the second experiment, two types of 
interactions between the three doses of the extract and MMC were carried out. In the first, the extract was orally given to the animals for seven days, while in day 8 , they were given MMC (5 mg/kg), and the investigation was carried out in day 9 (Pre-treatment). In the second type, MMC was given in day 1 , and the extract was given in the following seven days (Post-treatment). For each type of treatment, a control sample was investigated in a similar sequence, but the interaction was carried out between distilled water and MMC.

Laboratory Methods: The animals were investigated for the following parameters: total leucocyte count, mitotic index, micronucleus formation and chromosomal aberration. The leucocyte count was carried out on

\section{Results}

In table 1, the effect of the plant extract (three doses) on the investigated parameters is given together with the two controls. The negative controls showed a leucocyte count of 6783.3 cells/cu.mm.blood, which was significantly higher than the count in the positive controls

(3725.6 cells/cu.mm.blood). The first two doses (5 and $10 \mathrm{mg} / \mathrm{kg}$ ) of the plant extract peripheral blood that was obtained from the tail. For mitotic index, the cells were obtained from the bone marrow of the animals after treatment with colchicin, and at the same time the chromosomal aberrations were determined in 25 wellspread metaphases (8). The micronucleus formation was examined in bone marrow cells that were obtained from the femur of animals (9), and it is worth to mention that these animals were not treated with colchicin.

\section{Statistical Analaysis: Differences} between means were assessed by the least significant difference (LSD) by employing the computer programme SPSS. The difference was considered significant if the probability level was less than 0.05 .

approximated $\quad(5950.7 \quad$ and $\quad 6733.8$ cells/cu.mm.blood, respectively) the count of the negative controls, while the third dose $(15 \mathrm{mg} / \mathrm{kg})$ significantly increased such count (7634.4 vs. 6783.3 cells/cu.mm.blood). With respect to mitotic index, the three doses scored percentage means of $10.46,15.18$ and $17.87 \%$, respectively, and such values were significantly not different from the negative 
controls (14.93\%), but were significantly higher than the corresponding value in the positive controls (7.35\%). In the micronucleus assay, the MMC induced the formation of micronuclei in the bone marrow cells, and reached a mean of $13.52 \%$, which was significantly higher than the spontaneous formation of such micronuclei in the negative controls $(0.62 \%)$. However, the plant extract contribution in reducing the spontaneous formation of micronuclei was almost $50 \%$ of the negative control value in the three doses $(0.30,0.32$ and $0.29 \%$, respectively). Inspecting the chromosomal aberration assay revealed that the MMC treatment elevated the aberrations to 0.342 aberration/cell, which was significantly higher than either the negative control group (0.013 aberration/cell) or the three doses of nut grass (0.010, 0.009 and 0.012 aberration/cell, respectively).

Giving the plant extract before MMC (pretreatment) modulated the effect of MMC,

\section{Discussion}

The first part of this study demonstrated that the aqueous extract of nut grass did not affect the blood leucocyte count, although the dose $15 \mathrm{mg} / \mathrm{kg}$ increased the count significantly, an observation that may highlight the importance of this plant in especially the dose $15 \mathrm{mg} / \mathrm{kg}$, which enhanced the leucocyte count (10358.6 vs. 3800.2 cells/cu.mm.blood) and the mitotic index (11.9 vs. 6.5\%). However, the micronucleus assay contradicted such picture, and instead, the doses 5 and 10 $\mathrm{mg} / \mathrm{kg}$ were much more effective in reducing the MMC-induced micronuclei (4.24 and $5.96 \%$, respectively vs. 16.29\%). The chromosomal aberration assay shared the theme of micronucleus assay, and the extract reduced the aberration to $0.163,0.096$ and 0.079 aberration/cell, respectively for the doses 5, 10 and $15 \mathrm{mg} / \mathrm{kg}$. These differences were significant. A similar augmentation was drawn when the plant extract was given after MMC (post-treatment), and again the dose $15 \mathrm{mg} / \mathrm{kg}$ was the most effective in the assays of leucocyte count, mitotic index and chromosomal aberrations while the dose 5 $\mathrm{mg} / \mathrm{kg}$ scored the best results in the evaluation of micronucleus formation (Table 2).

shifting the leucocyte count positively. The same outcome is augmented when mitotic index, chromosomal aberrations and micronucleus formation in bone marrow cells are considered, although the spontaneous formi 
significantly decreased with no significant differences between the three doses. Such observations may qualify the safety of using the extract from the point view of investigated parameters, therefore, the profiles of plant's toxicity and/or genotoxicity can be excluded, and instead, the antimutagenic activity can be upgraded. On these bases, the plant extract was subjected to two types of interactions with the mutagen MMC (pre- and posttreatments). Both interactions were effective in modulating the effect of MMC, however, the dose, as well as, the parameter investigated may be effective in qualifying the extract as dsemutagen or bioantimutagen. Accordingly, the extract my exert its effect on the mutagen itself and/or act on the mechanism of DNA replication and enhance the systems of genetic repair profiles $(10,11)$.

Reviewing the literature about the mutagenic and antimutageic effects of $C$. rotundus revealed that the plant has not been extensively investigated, and only one paper has recently been issued (7). In this paper, the aerial parts of the plant were extracted with ethyl acetate and methanol, and subjected to a mutagenic assay using the Ames test. The results demonstrated the absence of mutagenicity for the different extracts of $C$. rotundus in all Salmonella tested strains, as well as, highlighted the importance of the plant constituents in reducing the mutagenic potentials of aflatoxin B1.

Preliminary chemical studies of $C$. rotundus revealed the presence of important quantities of flavonoids, tannins, coumarins essential oils, polyphenols, ascorbic acid and oleanolic acid $(5,7)$. These findings can be correlated with the mutagenic inhibitory effects observed with the extracts on induced mutagenicity. In fact, flavonoids $(12,13,14)$, coumarins (15), tannins (16), ascorbic acid $(17,18)$ and oleanolic acid (19) are known to have antimutagenic and/or anticarcinogenic effects. Such phytopharmacutical constituents are thought to inhibit lipid peroxidation and exert these effects as antioxidants, free radical scavengers, and chelators of divalent cations $(20,21)$.

It is too early to reach a final conclusion about the mutagenic effect of the present plant extract, but the observed antimutagenic activity and absence of mutagenicity of the extracts from $C$. rotundus, thus suggest that the extract may contain phytopharmaceutical molecules of interest. Other biological properties should be studied to evaluate their pharmacological potentials and to 
understand the mechanisms by which these

extracts act.

Table1: The effect of nut grass aqueous extract on total count of leucocytes, mitotic index, micronucleus formation and chromosomal aberrations in albino male mice.

\begin{tabular}{|c|c|c|c|c|c|}
\hline \multirow{2}{*}{\multicolumn{2}{|c|}{ Groups }} & \multicolumn{4}{|c|}{ Mean \pm Standard Error } \\
\hline & & $\begin{array}{c}\text { Leucocyte Count } \\
\text { (cells/cu.mm.blood) }\end{array}$ & $\begin{array}{c}\text { Mitotic Index } \\
(\%)\end{array}$ & $\begin{array}{c}\text { Micronucleus } \\
(\%)\end{array}$ & $\begin{array}{c}\text { Chromosomal } \\
\text { Aberrations } \\
\text { (aberration/cell) }\end{array}$ \\
\hline \multicolumn{2}{|c|}{ Negative Control } & $6783.3 \pm 240.1 \mathrm{a}$ & $14.93 \pm 2.23 \mathrm{a}$ & $0.62 \pm 0.07 a$ & $0.013 \pm 0.003 a$ \\
\hline \multicolumn{2}{|c|}{ Positive Control } & $3725.6 \pm 273.2 b$ & $7.35 \pm 1.98 b$ & $13.52 \pm 0.28 b$ & $0.342 \pm 0.026 b$ \\
\hline \multirow{3}{*}{ 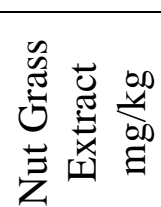 } & 5 & $5950.7 \pm 384.5 \mathrm{a}$ & $10.46 \pm 3.66 a$ & $0.30 \pm 0.07 \mathrm{c}$ & $0.010 \pm 0.002 \mathrm{a}$ \\
\hline & 10 & $6733.8 \pm 252.3 \mathrm{a}$ & $15.18 \pm 3.03 \mathrm{a}$ & $0.32 \pm 0.09 c$ & $0.009 \pm 0.004 a$ \\
\hline & 15 & $7634.4 \pm 331.5 c$ & $17.87 \pm 3.45 \mathrm{a}$ & $0.29 \pm 0.05 c$ & $0.012 \pm 0.003 a$ \\
\hline
\end{tabular}

*In the same column: similar letters refer to no significant difference $(\mathrm{P}>0.05)$, while different letters refer to significant difference $(\mathrm{P} \leq 0.05)$.

Table 2: The effect of interaction between nut grass aqueous extract and mitomycin $\mathrm{C}$ on total count of leucocytes, mitotic index and micronucleus formation in albino male mice.

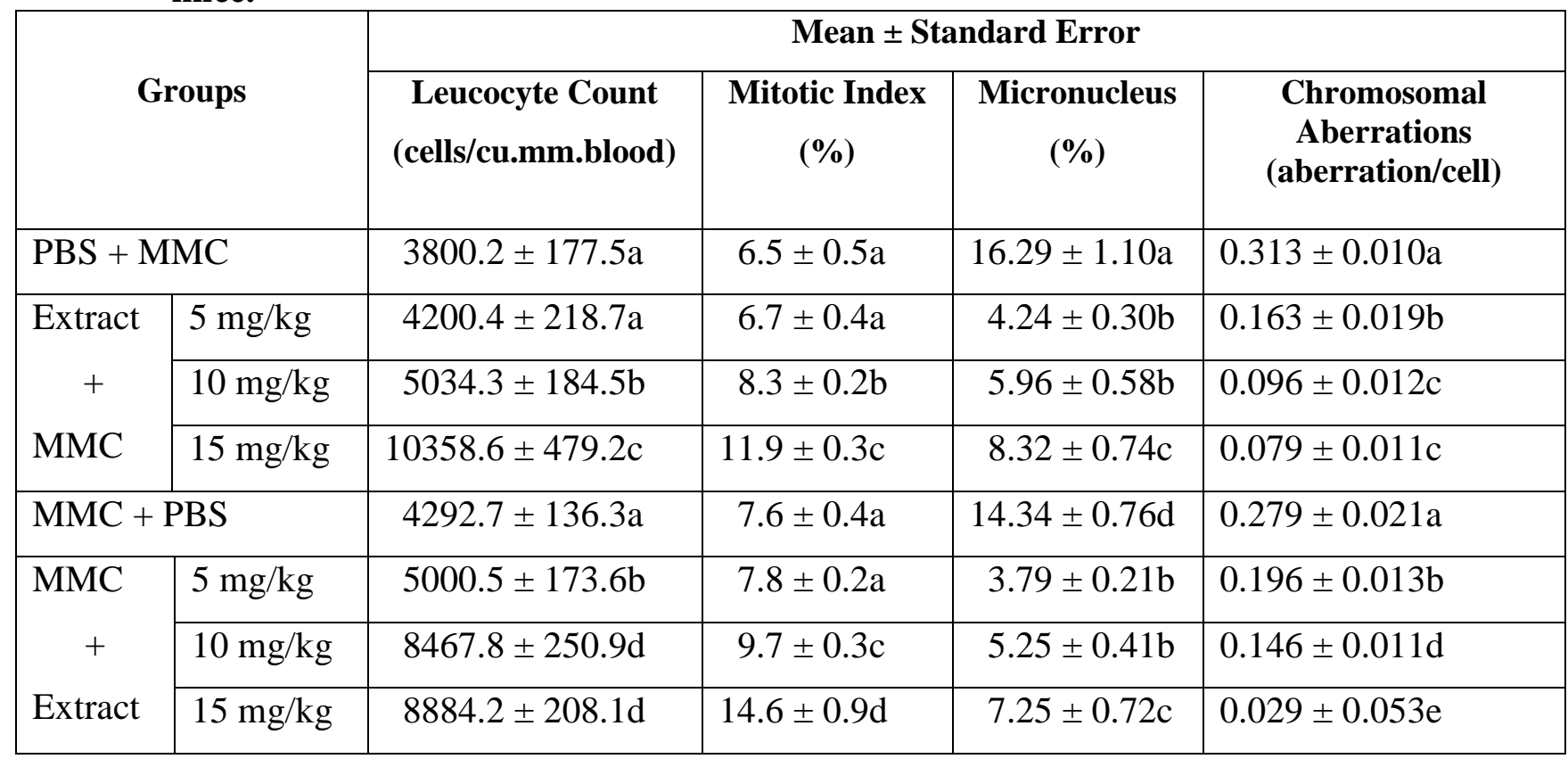

*In the same column: similar letters refer to no significant difference $(\mathrm{P}>0.05)$, while different letters refer to significant difference $(\mathrm{P} \leq 0.05)$. 


\section{References}

1. Oudhia, P. (2005) Motha or nut grass (Cyperus rotundus). Internet: 51 www.celestine-india.com/ pankajoudhia.

2. Duarte, M.C., Figueira, G.M., Sartoratto, A., Rehder, V. L. and Delarmelina, C. (2005) Anti-Candida activity of Brazilian medicinal plants. $J$. Ethnopharmacol., 97: 305-311.

3. Thebtaranonth, C., Thebtaranonth, Y., Wanauppathamkul, S. and Yuthavong Y. (1995) Antimalarial sesquiterpenes from tubers of Cyperus rotundus: structure of 10,12-peroxycalamenene, a sesquiterpene endoperoxide. Phytochemistry, 40:125-128.

4. Jagtap, A. G., Shirke, S.S. and Phadke, A. S. (2004) Effect of polyherbal formulation on experimental models of inflammatory bowel diseases. $J$. Ethnopharmacol., 90:195-204.

5. Huang, X. and Peng, G. (2003) Advances in the study of chemical constituents and pharmacology of Cyperus rotundus L. Zhong. Yao. Cai., 26:65-68.

6. Seo, W.G., Pae, H.-O., Oh, G.-S., Chai, K.-H., Kwon, T.-A., Yun, Y.-G., Kim, N.-Y. and Chung, H.-T., (2001) Inhibitory effect of methanolextract of Cyperus rotundus rhizomes on nitric oxide and superoxide productions by murine macrophage cell line, RAW 264.7 cells. $J$. Ethnopharmacol., 76: 59-64.

7. Kilani, S., Ben Ammar, R., Bouhlel, I., Abdelwahed, A., Hayder, N. Mahmoud, A., Ghedira, K.and ChekirGhedira, L (2005) Investigation of extracts from (Tunisian) Cyperus rotundus as antimutagens and radical scavengers . Environ. Toxicol. Pharmacol. (in press).

8. Ad'hiah, A. H., Syhood, Y. D. \& Shubber, E. K. (2004) Inhibiting the haematologic and cytogenetic effects of tamoxifen by alcoholic extract of garlic (Allium sativum). Nucleus, 47: 10-16.

9. Fenech M. (1993) Mouse and human micronucleus models for assessing genotoxicity of whole foods in intervention studies. Mutat. Res., 290: 119-125.

10. Kuroda, Y., Jain, A. K., Tezuka, H. and Koda, T. (1992) Antimutagenecity in cultured mammalian cells. Mutat. Res., 267: 201-209.

11. Bronzetti, G. (1997) The role of antimutagenesis and carcinogenesis. $J$. Environ. Pathol. Toxicol. Oncol., 16: 259262.

12. Calomme, M., Pieters, L., Vlietinek, A.and Berghe, D.V., 1996. Inhibition of bacterial mutagenesis by Citrus flavonoids. Planta Med., 62, 2: 
13. Rodriguez, J., Yanez, J., Vicente, V., Alcaraz, M., Benavente-Garcia, O., Castillo, J., Lorente, J. and Lozano, J. A. (2002) Effects of several flavonoids on the growth of B16F10 and SK-MEL-1 melanoma cell lines: relationship between structure and activity. Melanoma. Res., 12: 99-107.

14. da-Silva, J., Herrmann, S. M., Heuser, V., Peres, W., Possa-Marroni, N., Gonzalez-Gallego, J. and Erdtmann, B. (2002) Evaluation of the genotoxic effect of rutin and quercetin by comet assay and micronucleus test. Food. Chem. Toxicol., 40: 941-947.

15. Lee, K.T., Sohn II, C., Park, H.J., Kim, D.W., Jung, G.O. and Park, K.Y. (2000) Essential moiety for antimutagenic and cytotoxic activity of Hederagenin monodesmosides and bidesmosides isolated from the stem bark of Kalopanox pictus. Planta Med., 66: 329-332.

16. Schimmer, O. and Lindenbaum, $M$. (1995) Tannins with antimutagenic properties in the herb of Alchemilla species and Potentilla anserine. Planta Med., 61: 141-145.

17. Foyer, C. H. (2001) Prospects for enhancement of the soluble antioxidants, ascorbate and glutathione. Biofactors, 15: 75-78.

18. Aly, F. A. E. and Donya, S. M. (2002) In vivo antimutagenic effect of vitamins $\mathrm{C}$ and $\mathrm{E}$ against rifampicin-induced chromosome aberrations in mouse bonemarrow cells. Mutat. Res., 518: 1-7.

19. Li, J., Guo, W., J. and Yang, Q. Y. (2002) Effects of ursolic acid and oleanolic acid on human colon carcinoma cell line HCT15. World. J. Gastroenterol., 8: 493495.

20. Park, K.Y., Jung, G. O., Lee, K.T., Choi, J., Choi, M.Y., Kim, G.T., Jung, H. J. and Park, H.J. (2004) Antimutagenic activity of flavonoids from the heart wood of Rhus verniciflua. J. Ethnopharmacol., 90: 73-79.

21. Shon, M.Y., Choi, S.D., Kahng, G.G., Nam, S.H. and Sung, N. J. (2004) Antimutagenic, antioxidant and free radical scavenging activity of ethyl acetate extracts from white, yellow and red onions. Food. Chem. Toxicol., 42: 659-666. 